Cite this paper as : Gudivada VenkatRao \& VijayaLakshmi \& Rama Goswami (2017), "A STUDY ON FACTORS OF WORKPLACE HAPPINESS", International Journal of Marketing \& Financial Management, ISSN: 2348 -3954 (online) ISSN: 2349 -2546 (print), Volume 5,(Issue8, Aug-2017), pp 27-42, DOI URL:

\title{
A STUDY ON FACTORS OF WORKPLACE HAPPINESS
}

\author{
Dr. Gudivada Venkat Rao \\ Department of HRM, Dr. L. \\ Bullayya P.G. College, \\ Visakhapatnam,
}

\author{
Vijaya Lakshmi, \\ Department of Management \\ Studies, Dr. L.Bullayya \\ P.G.College, Viskhapatnam,
}

\author{
Rama Goswami \\ Department of Management \\ Studies, Dr. L.Bullayya \\ P.G.College,Visakhapatnam,
}

\begin{abstract}
Happiness is often equated with a form of mood or emotion. The term is often confused with the word satisfaction; both these terms are used simultaneously by many authors. The Psychologists attribute happiness as positive emotions in psychology. The factors of happiness and satisfaction at the workplace are a debatable issue. The happiness is the outcome of workplace practices or policies.
\end{abstract}

The present study was conducted with the objective of testing the level and influence of intrinsic, extrinsic and work life issues of happiness on faculty with three years experience drawn from STEM branches in a NAAC graded private higher education institute. The happiness factors were categorized into intrinsic factors with items associated with self-esteem, self-actualization which derives happiness to the individual from inner self, extrinsic factors with items as compensation, work environment, health and work-life issues with connected with flexibility, adjustment and counseling between work and family which derive happiness to the individual at the work place. The three factors of happiness i.e. intrinsic, extrinsic and work-life issues were analyzed with profile and employment factors by applying mean analysis and ANOVA statistical techniques.

The happiness at workplace is derived from all the three factors i.e. extrinsic, intrinsic and work life. The age as a factor of happiness at the work place is a significant factor. The work-life issues are important during the early period of employment and extrinsic are more important at advancing age. The choice of faculty as a profession is due to flexibility and happiness of faculty can be improved by providing flexible timings in the Organization.

Key Words: Happiness; Extrinsic factors of Happpiness; Intrinsic factors of Happiness; WorkLife issues of Happiness; Positive Emotion

\section{Introduction}

Happiness is often equated with a form of mood or emotion. The term in the present form was defined by Argyle (1987) as the positive inner feeling of an individual towards a particular aspect. The term happiness is viewed as a positive personnel feeling, contentment, pleasure, joy, gladness and enjoyment. Some authors view it as a moment. The term is often confused with the word satisfaction; both these terms are used simultaneously by many authors. The Psychologists attribute different meanings to satisfaction and happiness. The term is associated with positive organizational behavior (Luthans, 2002; Cropanzano \& Wright, 2001).

The psychological explanation for happiness is a particular moment in the transition process of behavior. But the happiness may be prolonged unlike the emotion in some circumstances. The happiness is derived on 
acceptance of the policy or practices of the organization. The differentiation between happiness and satisfaction is another complex set of issues where researchers were engaged. The Human Development Index was developed by United Nations Development Programme (UNDP) to measure the extent of development in response to society needs, in Bhutan the measure for development is the Happiness Index (Karma Ura, 2015). The World has designated $20^{\text {th }}$ March as International Happiness Day. The Happiness at the work place is the level of contentment of the employees and their feelings towards work and performance. The happiness at workplace is not to be confused with satisfaction. The happiness at workplace is inherent to the psychology of individual but whether it is source for satisfaction is a research question. The factors of happiness and satisfaction at the workplace are a debatable issue.

\section{Literature Review:}

The terms happiness, emotion, mood and satisfaction look similar but differ in scope and application. Some authors consider happiness, sadness, crying etc. as state of emotion. Emotion is an instantaneous response to a situation and endures for a shorter period. Mood is more inherent to the personality of individual, response to a situation and endures for a longer time. The state of happiness may be out of emotion or mood. The happiness is the outcome of workplace practices or policies. The happiness and satisfaction are different psychological states. The term satisfaction is the end and happiness may be a means to the end.

The Webster's dictionary meaning for happiness is "a state of well being with the emotions and synonyms with content, contentedness, contentment, enjoyment, gratification, pleasure, satisfaction". Seligman (2012) offers a more comprehensive view on happiness and defines it as "quality of individual life, emotional health, work environment, physical health, behavior and basic access favorably". The above five dimensions form the content variables for happiness. Happiness may be defined as the experience of frequent positive effect, infrequent negative affect and an overall sense of satisfaction with life as a whole (Myers \& Diener, 1995).

Jessica Pryce-Jones(2010) have defined Workplace Happiness as Happiness at work is about mindfully making the best use of the resources you have, to overcome the challenges you face. Actively relishing the highs and managing the lows will help you maximize your performance and achieve your potential. And this not only builds your happiness but also that of others who will be affected and energized by what you do.

The happiness is explained with two approaches, hedonic view of happiness is pleasant feelings and judgments of satisfaction which is subjective whereas eudemonic view point is well-being, self-validation and selfactualization (Warr, 2007; Seligman, 2002; Sheldon \& Elliot, 1999). The viewpoints clarifies, happiness is deriving pleasure from inner self and by doing what is right to the self.

Seligman, Martin E.P. (2002) approach to happiness as positive emotions has three dimensions, pleasure and gratification, Strengths and virtues and meaningful life. The strengths and virtues are encompassed with six core virtues and twenty four strengths. The present life is the positive emotions derived from past, present and future life. The goodlife is derived by indulging in activities which give gratification to the individual based on ones' strength. Thereby using the strengths and virtues in service, the individual presents larger life than the present to get a meaningful life and these manifests in happiness.

Figure 1: Seligman's Virtues and Courage's 

ISSN: 2348 -3954 (Online) ISSN: 2349 -2546 (Print),

\begin{tabular}{|c|c|c|c|c|c|}
\hline $\begin{array}{l}\text { Wisdom \& } \\
\text { Knowledge }\end{array}$ & Courage & $\begin{array}{l}\text { Love \& } \\
\text { Humanity }\end{array}$ & Justice & Temperance & $\begin{array}{l}\text { Spirituality \& } \\
\text { Transcendence }\end{array}$ \\
\hline $\begin{array}{l}\text { Acquiring And } \\
\text { Using Knowledge } \\
\text { Creativity } \\
\text { Curiosity } \\
\text { Open mindedness } \\
\text { Love Of Learning } \\
\text { Perspective And } \\
\text { Wisdom }\end{array}$ & $\begin{array}{l}\text { Bravery } \\
\text { Persistence } \\
\text { Integrity } \\
\text { Vitality }\end{array}$ & $\begin{array}{l}\text { Love } \\
\text { Kindness } \\
\text { Social } \\
\text { Intelligence }\end{array}$ & $\begin{array}{l}\text { Being An } \\
\text { Active Citizen } \\
\text { Socially } \\
\text { Responsible } \\
\text { Loyal And A } \\
\text { Team Member } \\
\text { Fairness } \\
\text { Leadership }\end{array}$ & $\begin{array}{l}\text { Forgiveness And } \\
\text { Mercy } \\
\text { Humility And } \\
\text { Modesty } \\
\text { Prudence } \\
\text { Self-Regulation } \\
\text { Self-Control }\end{array}$ & $\begin{array}{lr}\text { Appreciation } & \text { Of } \\
\text { Beauty } & \text { And } \\
\text { Excellence } & \\
\text { Gratitude } & \\
\text { Hope } & \\
\text { Humor } & \\
\text { Playfulness } & \\
\text { Spirituality, Or a } \\
\text { Sense Of Purpose }\end{array}$ \\
\hline
\end{tabular}

The constituents of happiness are matter for research. The contributors to happiness based on the metadata research are physical safety, physical health, wealth, community, fairness, being valued, trust, meaning, utilization, autonomy, positive emotions, work engagement, rewarding relationship, challenge of work, sense of purpose, leader influence, work-life balance, holistic approach and creativity(Andrews,2004). The happy people show four types of traits- emotional self esteem, a sense of control, optimism and extraversion. (Myers and Diener, 1995).

\section{Issues of Extrinsic and Intrinsic factors:}

The happiness is the outcome of combination of factors. The workplace is a texture of policies and practices of the organization. The influence of policies and practices on the employees may manifest in happiness. Herzberg et al. (1959) explaining the process of motivation has categorized the factors of motivation as intrinsic and extrinsic factors.

The intrinsic factors are content factors and often termed as motivators whereas context factors are hygienic in nature and classified as extrinsic factors. The intrinsic factors are achievement, recognition, rewards, appreciation, responsibility, advancement,growth, the work itself etc., and extrinsic factors are monetary rewards, fringe benefits, supervision, working conditions, co-workers, pay, policies and procedures. The intrinsic factors are strong orientation for achievement. The positive emotional status of individual towards work in the organization leads to satisfaction of job ((Wong, Hui, and Law, 1998; Jawahar and Hemmasi, 2006).

Andrew (2004) in his research work presents that rewards and recognitions are influencing the loyalty and commitment of an employee. The factors like supervision, working conditions, co-workers, pay, policies and procedures are considered to be extrinsic factors. In fact in the absence of these factors there is chance of causing dissatisfaction.

Harris and Eplion (2007) experimented for the impact of extrinsic factors and find positive relationship between job and performance of the employee. The job security is one of the extrinsic factor which is mainly concern about the level of responsibility and opportunity for advancement (Brotheridge, 2007).

The teachers motivation and their level of performance are interrelated (Lynn, 2002) but happiness as a factor of motivation is a nascent development area for the researchers. Furnham et.al(1992) studies, present satisfaction as the outcome variable with strong correlation between the salary and productivity. The facets of motivation are satisfaction levels with policies, supervision, pay, interpersonal relations, opportunities for promotion and growth, working conditions, work itself, achievement, recognition and responsibility (Ololube, 2005).

\section{Issues of Work Life Balance:}


The work life balance is often used in synonym with work -family balance (Hudson Resourcing, 2005). It refers to the multiple roles in a person's life, and satisfaction or happiness derived from performing the work-family activity. The work life balance is directly related with the achievement and enjoyment of employee within an organization. The work life balance practices within the organization use different terms. The organizational support for balancing the work-family issues with appropriate practices increases happiness at both the workplace and home (Estes\& Michael, 2005).

Catillo and Cano(2004) commented that when proper attention is given towards interpersonal relationship, recognition and supervision then the level of happiness among teachers in educational intuitions also increases. Karpin et.al. (1995) also added that happiness of teachers is determined by the degree to which the individual perceives job related needs are being satisfied.

The level of happiness of the teacher depends on the teaching performance and in turn this will increase the teacher's sense of responsibility.

\section{Satisfaction Vs Happiness:}

The satisfaction is derived when expectancy meets the rewards and performance (Vroom, 1964). The job satisfaction does not affect life satisfaction but whereas the life satisfaction effects the job satisfaction (Judge and Watanabe, 1994). Wheaton (1990) stated that self satisfaction purely depends on the personal traits. The National Workplace Happiness Survey (2014) was organized by Singapore Human Resources Institute (SHRI) with help of an instrument having 28 dimensions. These dimensions based on Maslow Need Hierarchy Theory were categorized into four elements Satisfaction, Alignment, Engagement and Well Being. The survey result presents happiness drivers at workplace as Brand Identity, Positive Emotions, Achievement, Culture, Role Identity and Hope. David G. Blanchflower and Andrew J. Oswald (2005) point a paradox from the report of Human Development Index which ranked Australia as third among a list of 134 participant countries. In their survey in 35 countries on Job Satisfaction at workplace Australia was ranked very low. Therefore, the Human Development and Job Satisfaction are not significantly related.

Di Tella et al (2003) on examining the mean life-satisfaction and happiness scores on Europeans and Americans find that only 30 percent are very happy or very satisfied. Here the researcher uses the words satisfied and very happy as synonyms. Diener (1984) based on statistical analysis from metadata from different studies on happiness concludes with the following observations- Money alone does not lead to happiness, happiness and age are related, the structure of happiness shows similar patterns in industrialized countries, happiness changes with time period and issues that give happiness changes with time. However, Shawan Achor (2017) has found a statistically significant relationship between happiness, travel, stress and energy. The results show happiness is given by stress free travel, advantageous at the workplace and give positive energy.

\section{Methodology}

The present study was conducted in a private higher education institute located in Visakhapatnam with highest NAAC grading. The sample cover includes the faculty members drawn from different streams of science, commerce and management with at least three years of experience. The sample was restricted to 53 for in-depth coverage of the research and it is approximately 30 per cent of the population in the universe. The survey was conducted with the aid of an instrument, which was developed based on literature review, existing instruments and expert opinion. The instrument with 39 items including Personal Profile and Employment Profile was tested for its validity and reliability by test-retest method and Cronbach Alpha Statistic. The actual questions on happiness were 25 and later these were categorized into factors as extrinsic, intrinsic and work-life issues.

The happiness factors were categorized into intrinsic and extrinsic factors similar to as defined under Herzberg Two theory and work-life issues. The extrinsic factor items derive happiness to the individual when provided at the workplace; the intrinsic factor items are associated with self-esteem, self-actualization which derives happiness to the individual from inner self. The Work Life factor includes items connected with flexibility, adjustment and counseling between work and family which derive happiness to the individual at the work place.

The Extrinsic Factor consists of 9 items $\quad: 1,2,3,4,5,9,15,18$ and 19 
The Intrinsic Factor consists of 10 items: 7,8,10,11,12,13,20,21,22 and 23

The Work Life issues consists of 6 items: 6, 14,16,17,24 and 25

The personal and employment profile considered for analyses are age, gender, qualification, marital status, spouse occupation, experience, number of children and type of family.

The three factors of happiness i.e. intrinsic, extrinsic and work-life issues were analyzed with profile and employment factors by applying mean analysis and ANOVA statistical techniques.

The following were the objectives of the study

- To determine the level of happiness of teaching faculty in educational institutions.

- To understand and analyse the intrinsic and extrinsic factors which influence happiness at the workplace.

- To understand the influence of work-life issues on happiness.

\section{RESULT AND DISCUSSION:}

The reliability of the data collected with the aid of 39 items schedule was tested with the help of Cronbach Alpha. The coefficient of the Cronbach Alpha is 0.64 and is within the level prescribed ( $>=0.60)$. The Cronbach Alpha results after standardization is 0.773 (see table number 1 ).

Table No. 1

\begin{tabular}{|c|c|c|}
\hline Cronbach's Alpha & $\begin{array}{c}\text { Cronbach's Alpha Based on Standardized } \\
\text { Items }\end{array}$ & No. of Items \\
\hline 0.640 & 0.773 & 39 \\
\hline
\end{tabular}

The average age of the sample respondents is 31.65 years. The other descriptive statistics of the sample are provided (see table number 2 and 3 ).

The ANOVA analysis between age and extrinsic, intrinsic and work-life factors of happiness were insignificant(table no.6) The extrinsic and intrinsic factors are major contributors of happiness for age group 45 and above whereas for less than 25 age group work-life factors are a priority for happiness. The relation of factors of happiness with gender is insignificant. The importance for factors vary based on gender, the extrinsic factors is important for men where else for females intrinsic factors are important. The mean analysis shows work-life issues are important based on highest qualification. The differentiation of extrinsic and intrinsic factors on educational qualification is marginal. The respondents with other qualifications rate extrinsic and intrinsic factors as high whereas work-life issues are ranked high on the happiness scale for $\mathrm{PhD}$ holders.

However, the ANOVA analysis between educational qualification and each of the factors of happiness is insignificant. The factors of happiness were examined for impact with marital status (table no.2). The mean analysis shows that teachers who are married have extrinsic and intrinsic factors of happiness ranked similarly. The Work life balance as a factor of happiness is given more preference by unmarried group than married and widows. The ANOVA analysis between marital status and each of the factors of happiness shows intrinsic and extrinsic have no significant relationship (table no.6).

The employees with unemployed spouses are having higher extrinsic and intrinsic factors influence on happiness. The employees with spouses who are running business have happiness influenced by work-life issues then those as employee or professional or any other. The data on spouse occupation springs a surprise; the employees with unemployed spouse have least influence of work-life issues on happiness. However, the ANOVA results are otherwise and needs further data which is beyond the scope of the present study. The results between happiness and extrinsic, intrinsic and work-life issues find no significant relation. 
The factors of happiness were examined for impact with experience (table no.3). The mean analysis shows extrinsic and intrinsic factors of happiness are ranked high for teachers having experience of 14 years and above. The Work life balance as a factor of happiness is given more preference by teachers having a less experience of 2 years or above 14 years of experience. The ANOVA analysis between experience and each of the factors of happiness shows extrinsic and work life balance issues have no significant relationship. But the intrinsic factors are significant at 10 percent level.

The number of children and factors of happiness were examined for priority and the analysis presents work life issues as a factor of happiness is given priority as the number of children requires. However, none of the factors of happiness are significant (table no.4). This is a major variation from the priority. The reasons attributed to working are financial support and share knowledge. The factors of happiness are insignificant with reasons for working. The reason for working is not a significant factor of happiness for teachers. Further it can be established from the study other factors are operating on happiness.

The factors of happiness were examined for impact with who motivated to join this profession (table no.3). The mean analysis shows intrinsic factors of happiness are ranked similarly for self and spouse group. The Work life balance as a factor of happiness is given more preference by any other group and self than others like parents spouse or friends. The priority for happiness with respect to extrinsic factor is high for self followed by any other and less for other motivators like parents spouse and friends. The ANOVA analysis between motivation factor and each of the factors of happiness shows none of the factors have significant relationship.

The factors of happiness were examined for impact with flexibility (table no.5). The mean analysis shows similar result for extrinsic and intrinsic factor. The Work life balance as a factor of happiness is given more preference by teachers having flexibility. The ANOVA analysis between flexibility and each of the factors of happiness shows intrinsic, extrinsic and work life balance have significant relationship.

The factors of happiness were examined for impact with roles performed. (table No.7). The mean analysis shows extrinsic factors of happiness are ranked similarly for teaching and other roles performed. The Work life balance as a factor of happiness is given more preference by those who perform other roles than teaching. The priority for happiness with respect to intrinsic factor is high for other roles performed than teaching. There is no significant relationship between roles performed and each of the factors of happiness.

\section{Conclusion}

The happiness at workplace is derived from all the three factors i.e. extrinsic, intrinsic and work life. The age as a factor of happiness at the work place is a significant factor. The Organization has to vary the inputs in extrinsic, intrinsic and work-life issues with the increase in the mean age in the organization. The work-life issues are important during the early period of employment and extrinsic are more important at advancing age.

The Organization has to create better flexibility for different age groups. The choice of teaching profession is due to flexibility in work aspects, flexibility with intrinsic factors and work-life issues are the reasons for choosing the faculty profession. The experience is influenced by intrinsic factor of happiness. The Organization can improve happiness at the workplace by providing for monetary and in-house facilities suitable to age and experience. The choice of faculty as a profession is due to flexibility and happiness of faculty can be improved by providing flexible timings in the Organization.

\section{REFERENCES:}

1. Andrew, S.S. (2009). The Servant Shepherd: A New Leadership Paradigm for Job Satisfaction and Happiness at the Workplace. In S. S. Sengupta (Ed.), Integrating Spirituality and Organizational Leadership, Macmillan Publishers, 377 -391.

2. Argyle M. (1987). The experience of happiness. London: Methuen

3. Castillo, J. X., \& Cano, J. (2004). Factors Explaining Job Satisfaction among Faculty. Journal of Agricultural Education, 45(3), 65-74 
4. Cropanzano R., \& Wright T.A. (2001). When a "happy" worker is really a productive worker: are view and further refinement of the happy-productive worker thesis. Consulting Psychology Journal: Practice\& Research, 53, 182-199

5. D Jessica Pryce-Jones(2010). Happiness at Work: Maximizing your Psychological Capital for Success, Oxford, UK: Wiley

6. David G. Blanchflower and Andrew J. Oswald (2005). Happiness and the Human Development Index: The Paradox of Australia.NBER Working Paper No. 11416, June.

7. Di Tella, Rafael, MacCulloch, Robert, and Oswald, Andrew J. (2003). The Macroeconomics of Happiness. Review of Economics and Statistics, 85, 809-827.

8. Diener, Edward (1984). Subjective Well-Being. Psychological Bulletin, 93, 542-575.

9. Estes, S. B., \& Michael, J. (2005). Work-family policies and gender inequality at work: A Sloan work and family encyclopaedia entry. Retrieved on March06,2017, from http://wfnetwork.bc.edu/encyclopedia_entry.php?id=1230\&area=All.

10. Furnham, A., \& Brewin, C. R. (1990). Personality and happiness. Personality and Individual Differences, 11, 1093-1096.

11. Harris, K. J., Harris, R. B., \& Eplion, D. M. (2007). Personality, leader-member exchanges, and work outcomes. Journal of Behavioral and Applied Management, 8(2),92-107.Retrieved from http://ibam.com/pubs/jbam/articles/vo18/no2/JBAM_8_2_1.pdf.

12. Herzberg, F., Mausner, B., \& Snyderman, B. B. (1959). The motivation to work (2nd ed.). New York: John Wiley \& Sons.

13. Hudson Resourcing (2005). The case for work/life balance: Closing the gap between policy and practice. Retrieved on March, $20^{\text {th }}, 2017$ from www.hudson.com.

14. Ito, J. \& Brotheridge, C. (2007). Exploring the predictors and consequences of job insecurity's components. Journal of Managerial Psychology, 22, 40-64.

15. Jawahar and Pegah Hemmasi, (2006).Perceived organizational support for women's advancement and turnover intentions: The mediating role of job and employer satisfaction. Women in Management Review, 21(8), 643-661.doi:10.1108/09649420610712036

16. Judge, T. A., \& Watanabe, S. (1994). Individual differences in the nature of the relationship between job and life satisfaction. Journal of Occupational and Organizational Psychology, 67,101-107.

17. Karma Ura (2015).The Experience of Gross National Happiness as Development Framework. ADB South Asia Working Paper Series, 42. Manila: Asian Development Bank.

18. Karpin et.al. (1995).Enterprising nations Reviewing Australia managers to meet the challenges of the Asia Pacific Century. Report on the Task force on leadership and management skills. Canberra: Australian Government publishing Service.

19. Luthans, F. (2002). The need for and meaning of positive organizational behaviour. Journal of Organizational Behaviour, 23, 695-706.

20. Lynn M., Snyder C. R. (2002). Uniqueness seeking. In Snyder C. R., Lopez S. J. (Eds.), Handbook of positive psychology (pp. 395-410). New York, NY: Oxford.

21. Myers, D.G., \& Diener, E. (1995). Who Is Happy?. Psychological Science, 6(1), 1017-19.

22. Ololube, N. P. (2005). Teachers' Job Satisfaction and Motivation for School Effectiveness: An Assessment. Retrieved on $20^{\text {th }}$ March,2017 from http://www.usca.edu/essays/vol182006/ololube.pdf.

23. Seligman(2012). Flourish: A Visionary new Understanding of Happiness and Well-being. New York: Free Press.

24. Seligman, Martin E.P. (2002). Authentic Happiness: Using the New Positive Psychology to Realize Your Potential for Lasting Fulfilment. New York, NY: Free Press.

25. Shawn Achor(2017).When a Vacation Reduces Stress- and When It Doesn't.Harvard Business ReviewSouth Asia,February-July,27-28.

26. Sheldon, K. M., \& Elliot, A. J. (1999). Goal striving, need-satisfaction, and longitudinal well-being: The Self-Concordance Model. Journal of Personality and SocialPsychology,76, 482-497.

27. The National Workplace Happiness Survey Annual Report-2014. Singapore Human Resources Institute, Singapore.

28. Vroom, V.H. (1964). Work and Motivation. New York: Wiley. 
29. Warr, P. (2007). Work, Happiness, and Unhappiness. New Jersey: Mahwah.

30. Wheaton (1990). Life transitions, role histories, and mental health. American Sociological Review, 55, 209-223.

31. Wong, C.S., Hui, C., and Law, K.S. (1998).A longitudinal study of the job perception-job satisfaction relationship: A test of the three alternative specifications. Journal of Occupational and Organizational Psychology,71,127-146.

\begin{tabular}{|c|c|c|c|c|c|c|c|c|c|}
\hline Age & & $\begin{array}{l}\text { Extrin } \\
\text {-sic }\end{array}$ & Intrinsic & $\begin{array}{l}\text { Work } \\
\text { Life }\end{array}$ & $\begin{array}{l}\text { Spouse } \\
\text { Occupation }\end{array}$ & & Extrinsic & Intrinsic & $\begin{array}{l}\text { Work } \\
\text { Life }\end{array}$ \\
\hline$>25$ & & 4.17 & 4.27 & 4.25 & Employee & $\mathrm{M}$ & 4.04 & 4.07 & 4.00 \\
\hline $25-35$ & & 4.01 & 3.92 & 4.05 & & S D & 0.34 & 0.36 & 0.37 \\
\hline $35-45$ & & 3.89 & 3.94 & 3.79 & Business & $\mathrm{M}$ & 4.02 & 3.98 & 4.03 \\
\hline $\begin{array}{l}45 \text { And } \\
\text { Above }\end{array}$ & & 4.37 & 4.43 & 4.14 & & SD & 0.14 & 0.47 & 0.24 \\
\hline Total & & 4.03 & 4.02 & 3.98 & Professional & $\mathrm{M}$ & 3.89 & 3.82 & 3.95 \\
\hline $\begin{array}{l}\text { Education } \\
\text { Qualification }\end{array}$ & & & & & & SD & 0.23 & 0.26 & 0.27 \\
\hline \multirow[t]{2}{*}{$\mathrm{PhD}$} & $\mathrm{M}$ & 4.04 & 3.85 & 4.11 & Unemployed & $\mathrm{M}$ & 4.12 & 4.15 & 3.93 \\
\hline & SD & $6.97 \mathrm{E}-$ & 0.37 & 0.18 & & SD & 0.24 & 0.42 & 0.26 \\
\hline \multirow[t]{2}{*}{$\mathrm{Pg}$} & $\mathrm{M}$ & 4.02 & 4.03 & 3.96 & Any Other & $\mathrm{M}$ & 4.03 & 3.90 & 4.00 \\
\hline & S D & 0.30 & 0.37 & 0.34 & & SD & 0.23 & 0.35 & 0.43 \\
\hline \multirow[t]{2}{*}{ Any Other } & $M$ & 4.17 & 4.31 & 3.91 & Total & $\mathrm{M}$ & 4.03 & 4.02 & 3.98 \\
\hline & S D & 0.15 & 0.32 & 0.35 & & S D & 0.27 & 0.37 & 0.32 \\
\hline \multirow[t]{2}{*}{ Total } & $\mathrm{M}$ & 4.03 & 4.02 & 3.98 & Experience & & & & \\
\hline & SD & 0.27 & 0.37 & 0.32 & $<2$ Years & $\mathrm{M}$ & 4.07 & 4.09 & 4.08 \\
\hline Gender & & & & & & S D & 0.10 & 0.12 & 0.11 \\
\hline \multirow[t]{2}{*}{ Male } & $\mathrm{M}$ & 4.06 & 4.00 & 3.98 & 2-6 Years & $\mathrm{M}$ & 3.98 & 3.91 & 3.97 \\
\hline & S D & 0.32 & 0.41 & 0.29 & & SD & 0.22 & 0.33 & 0.35 \\
\hline \multirow[t]{2}{*}{ Female } & $\mathrm{M}$ & 4.00 & 4.03 & 3.98 & 6-10 Years & $\mathrm{M}$ & 3.94 & 4 & 3.90 \\
\hline & $\mathrm{SD}$ & 0.23 & 0.34 & 0.36 & & S D & 0.22 & 0.36 & 0.40 \\
\hline Total & $\mathrm{M}$ & 4.03 & 4.02 & 3.98 & 10-14 Years & $\mathrm{M}$ & 3.99 & 3.85 & 4.02 \\
\hline
\end{tabular}




\begin{tabular}{|l|l|l|l|l|l|l|l|l|l|}
\hline & SD & 0.27 & 0.37 & 0.32 & & S D & 0.14 & 0.34 & 0.24 \\
\hline $\begin{array}{l}\text { Marital } \\
\text { Status }\end{array}$ & & & & & $\begin{array}{l}\text { Above 14 } \\
\text { Years }\end{array}$ & M & 4.19 & 4.24 & 4.04 \\
\hline Unmarried & M & 4.0714 & 3.9273 & 4.1 & & SD & 0.38 & 0.40 & 0.29 \\
\hline & SD & 0.1684 & 0.3993 & 0.2629 & Total & M & 4.03 & 4.02 & 3.98 \\
\hline Married & M & 4.0421 & 4.0536 & 3.9786 & & SD & 0.27 & 0.37 & 0.32 \\
\hline & SD & 0.2784 & 0.3878 & 0.3134 & $\begin{array}{l}\text { Roles } \\
\text { Perform }\end{array}$ & & & & \\
\hline Widow & M & 3.875 & 3.9545 & 3.7917 & Teaching & M & 4.03 & 4.016 & 3.98 \\
\hline & SD & 0.4787 & 0.1892 & 0.5672 & & S D & 0.283 & 0.38 & 0.33 \\
\hline Total & M & 4.035 & 4.0223 & 3.9874 & Other roles & M & 4.0357 & 4.18 & 4.08 \\
\hline & S D & 0.2776 & 0.3773 & 0.3282 & & S D & $5.05 \mathrm{E}-$ & 0.25 & 0.11 \\
\hline
\end{tabular}

Table No. 2: Means and Standard Deviations of the Variables

Table No 3: Means and Standard Deviations of the Variables

\begin{tabular}{|l|l|l|l|l|l|l|l|l|l|}
\hline No. Of Children & & $\begin{array}{l}\text { Extrin- } \\
\text { sic }\end{array}$ & $\begin{array}{l}\text { Intrin- } \\
\text { sic }\end{array}$ & $\begin{array}{l}\text { Work } \\
\text { Life }\end{array}$ & Motivation & & $\begin{array}{l}\text { Extrin } \\
\text {-sic }\end{array}$ & $\begin{array}{l}\text { Intrin- } \\
\text { sic }\end{array}$ & $\begin{array}{l}\text { Work } \\
\text { Life }\end{array}$ \\
\hline 0 & M & 3.95 & 4.03 & 3.86 & Self & M & 4.08 & 4.09 & 4.01 \\
\hline & SD & 0.26 & 0.22 & 0.49 & & SD & 0.25 & 0.41 & 0.29 \\
\hline & M & 3.97 & 3.98 & 4.03 & Parents & M & 3.98 & 3.91 & 3.95 \\
\hline & SD & 0.22 & 0.25 & 0.22 & & SD & 0.31 & 0.30 & 0.25 \\
\hline & M & 4.07 & 4.07 & 3.93 & Spouse & M & 3.95 & 4.03 & 3.97 \\
\hline 6 & SD & 0.34 & 0.45 & 0.37 & & SD & 0.35 & 0.20 & 0.51 \\
\hline & M & 4.07 & 3.94 & 4.1 & Friends & M & 3.71 & 3.81 & 3.16 \\
\hline Total & S.D & 0.16 & 0.41 & 0.26 & & SD &. &. &. \\
\hline & M & 4.03 & 4.02 & 3.98 & Any Other & M & 4 & 3.63 & 4.16 \\
\hline Type Of Family & SD & 0.27 & 0.37 & 0.32 & & SD & 0 & 0.51 & 0.23 \\
\hline
\end{tabular}




\begin{tabular}{|c|c|c|c|c|c|c|c|c|c|}
\hline Nuclear & $\mathrm{M}$ & 4.04 & 4.05 & 4.00 & & SD & 0.27 & 0.37 & 0.32 \\
\hline & SD & 0.28 & 0.41 & 0.36 & \multicolumn{5}{|l|}{ Flexibility } \\
\hline \multirow[t]{2}{*}{ Joint } & $\mathrm{M}$ & 4.00 & 3.99 & 3.94 & Yes & $\mathrm{M}$ & 4.18 & 4.13 & 4.14 \\
\hline & SD & 0.28 & 0.35 & 0.29 & & SD & 0.19 & 0.24 & 0.21 \\
\hline \multirow[t]{2}{*}{ Single } & $\mathrm{M}$ & 4.17 & 3.95 & 4.25 & No & $\mathrm{M}$ & 3.95 & 4.09 & 3.86 \\
\hline & SD & $\begin{array}{l}5.05 \mathrm{E}- \\
02\end{array}$ & $\begin{array}{l}6.43 \mathrm{E}- \\
02\end{array}$ & $\begin{array}{l}0.117 \\
9\end{array}$ & & $\mathrm{SD}$ & 0.36 & 0.44 & 0.41 \\
\hline \multirow[t]{2}{*}{ Total } & $\mathrm{M}$ & 4.03 & 4.02 & 3.98 & Partly & $\mathrm{M}$ & 3.97 & 3.81 & 3.96 \\
\hline & S D & 0.27 & 0.37 & 0.32 & & SD & 0.15 & 0.33 & 0.25 \\
\hline \multicolumn{4}{|c|}{ Reasons For Working } & & Total & M & 4.03 & 4.02 & 3.98 \\
\hline \multirow[t]{2}{*}{ Independent } & $\mathrm{M}$ & 3.98 & 3.95 & 3.83 & & SD & 0.2 & 0.37 & 0.32 \\
\hline & SD & 0.22 & 0.23 & 0.38 & Reasons Fo & Choc & & & \\
\hline \multirow[t]{2}{*}{ Share Knowledge } & $\begin{array}{l}\text { Mea } \\
\mathrm{n}\end{array}$ & 4.09 & 4.13 & 4.029 & $\begin{array}{l}\text { Self } \\
\text { Interest }\end{array}$ & $\mathrm{M}$ & 4.04 & 4.05 & 3.99 \\
\hline & SD & 0.18 & 0.32 & 0.30 & & SD & 0.29 & 0.35 & 0.31 \\
\hline \multirow[t]{2}{*}{ Financial Support } & $\mathrm{M}$ & 3.99 & 3.93 & 3.99 & $\begin{array}{l}\text { No Oppor- } \\
\text { tunties }\end{array}$ & $\mathrm{M}$ & 3.8 & 3.84 & 3.61 \\
\hline & S D & 0.37 & 0.47 & 0.30 & & S D & 0.10 & 0.64 & 0.38 \\
\hline \multirow[t]{2}{*}{ Any Other } & $\mathrm{M}$ & 4.12 & 4.18 & 4.25 & $\begin{array}{l}\text { Any Other } \\
\text { Reason }\end{array}$ & $\mathrm{M}$ & 4.04 & 3.72 & 4.22 \\
\hline & SD & 0.10 & 0.25 & 0.16 & & SD & $4.12 \mathrm{E}-$ & 0.45 & 0.19 \\
\hline \multirow[t]{2}{*}{ Total } & $\mathrm{M}$ & 4.03 & 4.02 & 3.98 & Total & $\mathrm{M}$ & 4.03 & 4.02 & 3.98 \\
\hline & S D & 0.27 & 0.37 & 0.32 & & SD & 0.27 & 0.37 & 0.32 \\
\hline & & & & & & & & & \\
\hline
\end{tabular}




\begin{tabular}{|c|c|c|c|c|c|c|c|}
\hline \multicolumn{3}{|l|}{ Experience } & \multirow{2}{*}{$\begin{array}{l}\begin{array}{l}\text { Sum Of } \\
\text { Squares }\end{array} \\
0.547\end{array}$} & \multirow{2}{*}{\begin{tabular}{|l|} 
Df \\
4 \\
\end{tabular}} & \multirow{2}{*}{$\begin{array}{l}\begin{array}{l}\text { Mean } \\
\text { Square }\end{array} \\
0.137\end{array}$} & \multirow{2}{*}{$\begin{array}{l}\text { F } \\
1.898\end{array}$} & \multirow{2}{*}{$\begin{array}{l}\text { Sig. } \\
0.126 \\
\end{array}$} \\
\hline Extrinsic * Experience & Between Groups & (Combined) & & & & & \\
\hline & Within Groups & & 3.459 & 48 & 0.072 & & \\
\hline & Total & & 4.006 & 52 & & & \\
\hline \multirow[t]{3}{*}{ Intrinsic * Experience } & Between Groups & (Combined) & 1.125 & 4 & 0.281 & 2.151 & $0.089^{* * * *}$ \\
\hline & Within Groups & & 6.278 & 48 & 0.131 & & \\
\hline & Total & & 7.403 & 52 & & & \\
\hline \multirow[t]{3}{*}{$\mathrm{Wl} *$ Experience } & Between Groups & (Combined) & 0.175 & 4 & 0.044 & 0.387 & 0.817 \\
\hline & Within Groups & & 5.428 & 48 & 0.113 & & \\
\hline & Total & & 5.603 & 52 & & & \\
\hline \multicolumn{8}{|l|}{ No. of Children } \\
\hline \multirow{3}{*}{$\begin{array}{l}\text { Extrinsic * No. Of } \\
\text { Children }\end{array}$} & Between Groups & (Combined) & 0.146 & 3 & 0.049 & 0.618 & 0.607 \\
\hline & Within Groups & & 3.86 & 49 & 0.079 & & \\
\hline & Total & & 4.006 & 52 & & & \\
\hline \multirow{3}{*}{$\begin{array}{l}\text { Intrinsic * No. Of } \\
\text { Children }\end{array}$} & Between Groups & (Combined) & 0.142 & 3 & 0.047 & 0.319 & 0.811 \\
\hline & Within Groups & & 7.261 & 49 & 0.148 & & \\
\hline & Total & & 7.403 & 52 & & & \\
\hline \multirow[t]{3}{*}{ Wl * No. Of Children } & Between Groups & (Combined) & 0.295 & 3 & 0.098 & 0.908 & 0.444 \\
\hline & Within Groups & & 5.308 & 49 & 0.108 & & \\
\hline & Total & & 5.603 & 52 & & & \\
\hline \multicolumn{8}{|l|}{ Type Of Family } \\
\hline \multirow{3}{*}{$\begin{array}{l}\text { Extrinsic * Type Of } \\
\text { Family }\end{array}$} & Between Groups & (Combined) & 0.065 & 2 & 0.033 & 0.415 & 0.663 \\
\hline & Within Groups & & 3.941 & 50 & 0.079 & & \\
\hline & Total & & 4.006 & 52 & & & \\
\hline \multirow{2}{*}{$\begin{array}{l}\text { Intrinsic * Type Of } \\
\text { Family }\end{array}$} & Between Groups & (Combined) & 0.055 & 2 & 0.027 & 0.186 & 0.831 \\
\hline & Within Groups & & 7.349 & 50 & 0.147 & & \\
\hline
\end{tabular}




\begin{tabular}{|l|l|l|l|l|l|l|l|}
\hline & Total & & 7.403 & 52 & & & \\
\hline $\mathrm{Wl}$ * Type Of Family & Between Groups & (Combined) & 0.195 & 2 & 0.097 & 0.901 & 0.413 \\
\hline & Within Groups & & 5.408 & 50 & 0.108 & & \\
\hline & Total & & 5.603 & 52 & & & \\
\hline
\end{tabular}

Table No. 4: ANOVA Results for Experience, No. Of Children, Type of Family with the Factors of

\section{Happiness}

***Significant at 10 per cent level

Table No. 5: ANOVA Results for Experience, No. Of Children, Type of Family with the Factors of Happiness

\begin{tabular}{|c|c|c|c|c|c|c|c|}
\hline Reasons For Working & & & $\begin{array}{l}\text { Sum Of } \\
\text { Squares }\end{array}$ & $\mathrm{Df}$ & $\begin{array}{l}\text { Mean } \\
\text { Square }\end{array}$ & $\mathrm{F}$ & Sig. \\
\hline \multirow{3}{*}{$\begin{array}{l}\text { Extrinsic * Reasons For } \\
\text { Working }\end{array}$} & Between Groups & (Comb) & 0.159 & 3 & 0.053 & 0.675 & 0.572 \\
\hline & Within Groups & & 3.847 & 49 & 0.079 & & \\
\hline & Total & & 4.006 & 52 & & & \\
\hline \multirow{3}{*}{$\begin{array}{l}\text { Intrinsic * Reasons For } \\
\text { Working }\end{array}$} & Between Groups & (Comb) & 0.552 & 3 & 0.184 & 1.317 & 0.28 \\
\hline & Within Groups & & 6.851 & 49 & 0.14 & & \\
\hline & Total & & 7.403 & 52 & & & \\
\hline \multirow{3}{*}{$\begin{array}{l}\text { Wl * Reasons For } \\
\text { Working }\end{array}$} & Between Groups & (Comb) & 0.591 & 3 & 0.197 & 1.926 & 0.138 \\
\hline & Within Groups & & 5.012 & 49 & 0.102 & & \\
\hline & Total & & 5.603 & 52 & & & \\
\hline \multicolumn{8}{|l|}{ Reasons For Choosing } \\
\hline \multirow{3}{*}{$\begin{array}{l}\text { Extrinsic * Reasons For } \\
\text { Choosing }\end{array}$} & Between Groups & (Comb) & 0.076 & 2 & 0.038 & 0.48 & 0.621 \\
\hline & Within Groups & & 3.931 & 50 & 0.079 & & \\
\hline & Total & & 4.006 & 52 & & & \\
\hline $\begin{array}{l}\text { Intrinsic * Reasons For } \\
\text { Choosing }\end{array}$ & Between Groups & (Comb) & 0.394 & 2 & 0.197 & 1.405 & 0.255 \\
\hline
\end{tabular}




\begin{tabular}{|c|c|c|c|c|c|c|c|}
\hline & Within Groups & & 7.01 & 50 & 0.14 & & \\
\hline & Total & & 7.403 & 52 & & & \\
\hline \multirow{3}{*}{$\begin{array}{l}\text { Wl * Reasons For } \\
\text { Choosing }\end{array}$} & Between Groups & (Comb) & 0.594 & 2 & 0.297 & 2.965 & $0.061^{* * * 1}$ \\
\hline & Within Groups & & 5.009 & 50 & 0.1 & & \\
\hline & Total & & 5.603 & 52 & & & \\
\hline \multicolumn{8}{|l|}{ Flexibility } \\
\hline \multirow[t]{3}{*}{ Extrinsic * Flexibility } & Between Groups & (Comb) & 0.567 & 2 & 0.284 & 4.122 & $0.022^{* *}$ \\
\hline & Within Groups & & 3.439 & 50 & 0.069 & & \\
\hline & Total & & 4.006 & 52 & & & \\
\hline \multirow[t]{3}{*}{ Intrinsic * Flexibility } & Between Groups & (Comb) & 1.03 & 2 & 0.515 & 4.041 & $0.024^{\pi k \pi}$ \\
\hline & Within Groups & & 6.373 & 50 & 0.127 & & \\
\hline & Total & & 7.403 & 52 & & & \\
\hline \multirow[t]{3}{*}{ W1* Flexibility } & Between Groups & (Comb) & 0.73 & 2 & 0.365 & 3.748 & $0.03 * *$ \\
\hline & Within Groups & & 4.872 & 50 & 0.097 & & \\
\hline & Total & & 5.603 & 52 & & & \\
\hline
\end{tabular}

**Significant at 5 percent level

*** Significant at 10 percent level.

\begin{tabular}{|l|l|l|l|l|l|l|l|}
\hline \multicolumn{2}{|l|}{ Gender } & $\begin{array}{l}\text { Sum of } \\
\text { Squares }\end{array}$ & df & $\begin{array}{l}\text { Mean } \\
\text { Square }\end{array}$ & F & Sig. \\
\hline Extrinsic * Gender & Between Groups & $(\mathrm{Comb})$ & 0.04 & 1 & 0.04 & 0.62 & 0.43 \\
\hline & Within Groups & & 3.95 & 51 & 0.07 & & \\
\hline & Total & & 4.00 & 52 & & & \\
\hline Intrinsic* Gender & Between Groups & $($ Comb) & 0.01 & 1 & 0.01 & 0.08 & 0.77 \\
\hline & Within Groups & & 7.39 & 51 & 0.14 & & \\
\hline & Total & & 7.40 & 52 & & & \\
\hline W1 * Gender & Between Groups & $(\mathrm{Comb})$ & 0 & 1 & 0 & 0 & 0.99 \\
\hline
\end{tabular}




\begin{tabular}{|c|c|c|c|c|c|c|c|}
\hline & Within Groups & & 5.60 & 51 & 0.11 & & \\
\hline & Total & & 5.60 & 52 & & & \\
\hline \multicolumn{8}{|l|}{ Marital Status } \\
\hline \multirow[t]{3}{*}{ Extrinsic* Marital Stat } & Between Groups & (Comb) & 0.118 & 2 & 0.059 & 0.756 & 0.475 \\
\hline & Within Groups & & 3.889 & 50 & 0.078 & & \\
\hline & Total & & 4.006 & 52 & & & \\
\hline \multirow[t]{3}{*}{ Intrinsic * Marital Stat } & Between Groups & (Comb) & 0.147 & 2 & 0.073 & 0.506 & 0.606 \\
\hline & Within Groups & & 7.256 & 50 & 0.145 & & \\
\hline & Total & & 7.403 & 52 & & & \\
\hline \multirow[t]{3}{*}{ W1 * Marital Stat } & Between Groups & (Comb) & 0.283 & 2 & 0.142 & 1.33 & 0.274 \\
\hline & Within Groups & & 5.32 & 50 & 0.106 & & \\
\hline & Total & & 5.603 & 52 & & & \\
\hline \multicolumn{8}{|l|}{ Age } \\
\hline \multirow[t]{3}{*}{ Extrinsic * Age } & Between Groups & (Comb) & 1.338 & 3 & 0.446 & 8.187 & 0* \\
\hline & Within Groups & & 2.669 & 49 & 0.054 & & \\
\hline & Total & & 4.006 & 52 & & & \\
\hline \multirow[t]{3}{*}{ Intrinsic* Age } & Between Groups & (Comb) & 1.802 & 3 & 0.601 & 5.254 & 0.003* \\
\hline & Within Groups & & 5.601 & 49 & 0.114 & & \\
\hline & Total & & 7.403 & 52 & & & \\
\hline \multirow[t]{3}{*}{$\mathrm{Wl} *$ Age } & Between Groups & (Comb) & 1.105 & 3 & 0.368 & 4.012 & $0.012 *$ \\
\hline & Within Groups & & 4.498 & 49 & 0.092 & & \\
\hline & Total & & 5.603 & 52 & & & \\
\hline & & & & & & & \\
\hline & & & & & & & \\
\hline
\end{tabular}

Table No. 6: ANOVA Results for Gender, Marital Status, Age with the Factors of Happiness

*Significant at 1 per cent level

Table No. 7: ANOVA Results for Educational Qualification, Spouse Occupation, and Roles Performed with the Factors of Happiness 


\begin{tabular}{|c|c|c|c|c|c|c|c|}
\hline $\begin{array}{l}\text { Educational } \\
\text { Qualification }\end{array}$ & & & $\begin{array}{l}\text { Sum of } \\
\text { Squares }\end{array}$ & df & $\begin{array}{l}\text { Mean } \\
\text { Square }\end{array}$ & $\mathbf{F}$ & Sig. \\
\hline \multirow[t]{3}{*}{ Extrinsic * Edu Qual } & Between Groups & (Comb) & 0.044 & 2 & 0.022 & 0.277 & 0.759 \\
\hline & Within Groups & & 3.962 & 50 & 0.079 & & \\
\hline & Total & & 4.006 & 52 & & & \\
\hline \multirow[t]{3}{*}{ Intrinsic * Edu Qual } & Between Groups & (Comb) & 0.373 & 2 & 0.187 & 1.327 & 0.274 \\
\hline & Within Groups & & 7.03 & 50 & 0.141 & & \\
\hline & Total & & 7.403 & 52 & & & \\
\hline \multirow[t]{3}{*}{ Wl * EduQual } & Between Groups & (Comb) & 0.145 & 2 & 0.073 & 0.665 & 0.519 \\
\hline & Within Groups & & 5.458 & 50 & 0.109 & & \\
\hline & Total & & 5.603 & 52 & & & \\
\hline \multicolumn{8}{|l|}{ Spouse Occupation } \\
\hline \multirow{3}{*}{$\begin{array}{l}\text { Extrinsic } * \text { Spouse } \\
\text { Occupation }\end{array}$} & Between Groups & (Combined) & 0.262 & 4 & 0.065 & 0.838 & 0.508 \\
\hline & Within Groups & & 3.745 & 48 & 0.078 & & \\
\hline & Total & & 4.006 & 52 & & & \\
\hline \multirow{3}{*}{$\begin{array}{l}\text { Intrinsic * Spouse } \\
\text { Occupation }\end{array}$} & Between Groups & (Combined) & 0.673 & 4 & 0.168 & 1.199 & 0.323 \\
\hline & Within Groups & & 6.731 & 48 & 0.14 & & \\
\hline & Total & & 7.403 & 52 & & & \\
\hline \multirow[t]{3}{*}{ W1 * Spouse Occupation } & Between Groups & (Combined) & 0.053 & 4 & 0.013 & 0.114 & 0.977 \\
\hline & Within Groups & & 5.55 & 48 & 0.116 & & \\
\hline & Total & & 5.603 & 52 & & & \\
\hline \multicolumn{8}{|l|}{ Roles Performed } \\
\hline \multirow[t]{3}{*}{$\begin{array}{l}\text { Extrinsic* Roles } \\
\text { Performed }\end{array}$} & Between Groups & (Comb) & 0 & 1 & 0 & 0 & 0.997 \\
\hline & Within Groups & & 4.006 & 51 & 0.079 & & \\
\hline & Total & & 4.006 & 52 & & & \\
\hline $\begin{array}{l}\text { Intrinsic * Roles } \\
\text { Performed }\end{array}$ & Between Groups & (Comb) & 0.053 & 1 & 0.053 & 0.367 & 0.547 \\
\hline
\end{tabular}




\begin{tabular}{|l|l|l|l|l|l|l|l|}
\hline & Within Groups & & 7.351 & 51 & 0.144 & & \\
\hline & Total & & 7.403 & 52 & & & \\
\hline WL * Roles Performed & Between Groups & (Combined) & 0.019 & 1 & 0.019 & 0.175 & 0.678 \\
\hline & Within Groups & & 5.584 & 51 & 0.109 & & \\
\hline & Total & & 5.603 & 52 & & & \\
\hline
\end{tabular}

